\title{
Potential of chitosan alone and in combination with agricultural wastes against the root-knot nematode, Meloidogyne incognita infesting eggplant
}

\author{
Mohd Asif*, Faheem Ahmad, Moh Tariq, Amir Khan, Taruba Ansari, \\ Faryad Khan, Ahmad M. Siddiqui \\ Section of Plant Pathology and Nematology, Department of Botany, Aligarh Muslim University, Aligarh, India
}

Vol. 57, No. 3: 288-295, 2017

DOI: 10.1515/jppr-2017-0041

Received: June 09, 2017

Accepted: September 19, 2017

${ }^{*}$ Corresponding address: asifgc2616@gmail.com

\begin{abstract}
The present investigation was carried out to evaluate the potential of chitosan alone and in combination with various agricultural wastes for the management of rootknot nematode, Meloidogyne incognita on eggplant cv. 'BR-112' under greenhouse conditions. The results showed that chitosan as a single or joint treatment with agricultural wastes significantly ( $\mathrm{p} \leq 0.05$ ) reduced root-knot indices, and the nematode population in soil. As a result, of this, the growth and growth yielding attributes of eggplant were remarkably augmented. Chitosan as an elicitor induced plant mediated systemic resistance against $M$. incognita in eggplant. The results of the study demonstrated that maximum reduction in eggmass/root, eggs/eggmasses, nematode population and root-knot indices, was acquired by the treatments: chitosan + onion and chitosan + mentha. It was followed by chitosan + Brassica, chitosan + urad and chitosan + coconut whereas, chitosan combined with corn cob waste was found to be the least effective when compared to the control. The application of chitosan alone was effective but not very satisfactory. Compared to the control applications of all the treatments significantly increased plant growth in terms of length, fresh and dry weights, pollen fertility, yield and biochemical parameters such as chlorophyll, carotenoid content and antioxidant enzymes. This may have been due to the eliciting activity of chitosan, causing systemic resistance in the plant and the release of various toxic chemical compounds during decomposition which have lethal effects against the second stage juveniles of $M$. incognita and nematode multiplication.
\end{abstract}

Key words: agricultural wastes, eggplant, chitosan, Meloidogyne incognita, root-knot nematode

\section{Introduction}

Vegetables are essential components of our routine diet due to their nutritional importance. They play a significant role as sources of various vitamins (C, A, B6, thiamine, niacin, E) minerals and dietary fiber. India is the second largest producer of eggplants (11896000 MT - metric ton) in world production (FAO 2011). Root-knot nematode (Meloidogyne spp.) is one of the limiting factors affecting the production of eggplant (Solanum melongena L.) in India (Singh and Sharma
1998). It constitutes a major group of plant-parasitic nematodes causing extensive economic damage to approximately all crop plants of economic importance in both tropical and sub-tropical crop production regions all over the world (Sikora and Fernandez 2005). Plant-parasitic nematodes attack plants and are usually ubiquitous with high rates of reproduction, making it difficult to manage them. Therefore cause significant damage and yield losses in crops (Luc et al. 2005). 
Nematode management can be defined as a practice whereby the root-knot nematode population is kept at low levels that do not cause economic losses in various crops. Plant-parasitic nematodes are commonly controlled by cultural practices, chemical nematicides and by the growing of resistant cultivars (Curto et al. 2006). Chemical control is expensive and is economically viable only for high value crops. Furthermore it creates a potential hazard to the environment and human health. Therefore, alternative nematode control methods or less toxic nematicides need to be developed (Ploeg 2008). One way to overcome these environmental and health issues is to characterize and identify novel and naturally occurring phytoconstituents in the plants that are environmentally friendly, facile and promote soil conditioning activity. The use of plant parts and organic matter for the management of plant-parasitic nematodes in agronomic crops has been widely studied by several workers and nematode populations have been positively or negatively correlated with the organic matter content (Asif et al. 2016). Chitosan is a polysaccharide deacetylated derivative of chitin. It is made from the outer shell of crustaceans and cell walls of certain fungi. It has been reported that chitosan displayed elicitor activity by inducing local and systemic resistance mechanisms of tomato plants against the root-knot nematode, M. incognita (Radwan et al. 2012). Several studies have shown that chitosan can induce plant resistance to several pathogens by restricting pathogen growth and/or by eliciting several defense mechanisms (Rabea et al. 2003). There are many reports on combined applications of chitin/chitosan with biotic or abiotic agents. Combining the use of chitin or chitosan with biocontol agents might result in synergistic, additive or antagonistic effects against root-knot nematodes. Commercially-available rhizobacterial inoculants sold as BioYield ${ }^{\circledR}$, (two PGPR strains of Bacillus spp. + chitosan), induced significant reductions in nematode eggs in roots, juvenile nematodes in soil, and galls per plant on tomato (Burkett-Cadena et al. 2008). Similarly, the combined effect of chitosan with Bacillus megaterium $\left(\right.$ Bioarc $^{\circledR}$ ) showed additive interaction effects on the reduction of $M$. incognita on tomato (Radwan et al. 2011). However, none of the management tactics alone is very efficient for the management of nematode. The management of nematode in an integrated manner may be one of the best strategies to overcome this nematode problem. Therefore, the present investigation was conducted with the aim of testing the potential of chitosan alone and in combination with various agricultural wastes viz., onion, mentha, brassica, urad, coconut shell, groundnut shell and corn cob wastes against root-knot nematode infestation and growth, as well as growth yielding attributes of eggplant under greenhouse conditions.

\section{Materials and Methods}

The experiment was carried out under greenhouse conditions in the Department of Botany, Aligarh Muslim University Aligarh. Medium size earthen clay pots (15 cm diameter) were filled with $1 \mathrm{~kg}$ autoclaved soil. The average temperature ranged from $28-38^{\circ} \mathrm{C}$ with a scanty rainfall of $65-75 \mathrm{~cm}$ as seen throughout the year. Eggplant was selected as a test plant and rootknot nematode, $M$. incognita was chosen as a test pathogen to evaluate the potential of chitosan alone and in combination with various agricultural wastes. Root-knot nematode infected roots were collected from Agra Road, Aligarh, India. Infected roots of the plants were gently uprooted from the soil, kept in polythene bags and then labeled. All the collected samples were brought to the laboratory for examination. Juveniles of $M$. incognita were obtained from a pure culture that was previously cultured by eggmasses and propagated on eggplant in the greenhouse of the Section of Plant Pathology and Plant Nematology, Department of Botany, Aligarh Muslim University, Aligarh, India. The swollen female was detached from the gall of an infected root with the help of a dissecting needle and identified according to its perineal pattern. For nursery preparation, surface sterilized seeds of eggplant were sown in autoclaved clay pots $(30 \mathrm{~cm}$ diameter) filled with soil. A mixture of soil and organic manure was prepared at the ratio of $3: 1(\mathrm{pH}=7.5$, available $\mathrm{N}=1 \mathrm{~g} \cdot \mathrm{kg}^{-1}$ soil and available $\mathrm{P}=8.79 \mathrm{mg} \cdot \mathrm{kg}^{-1}$ soil). Chitosan, in the form of a fine powder was procured from Sigma-Aldrich. Three weeks after germination, one eggplant seedling at the two leaf stage was transplanted to each clay pot $(15 \mathrm{~cm}$ diameter $)$ filled with $1 \mathrm{~kg}$ autoclaved soil. These pots were treated with chitosan (1.5 g alone) and in combination with decomposed agriculture wastes (15 $\mathrm{g}$ of different agriculture crops viz., corn cob, brassica, mentha, urad, groundnut shell, coconut shell and onion). Four replications of each treatment were arranged in a completely randomized design (CRD). Fifteen days after transplantation when the seedlings were acclimatized and the roots were get stabilized, each plant was inoculated with 1,500 newly hatched second stage juveniles (J2) of M. incognita by making 3-4 holes in the pots without disturbing the root system.

\section{Pot experiment}

The eggmasses were counted following the procedure of Daykin and Hussey (1985). For extraction of nematodes from the soil, $250 \mathrm{~g}$ of well-mixed soil from each treatment was processed by Cobb'ssieving and decanting method followed by the Baermann funnel method. The nematode suspension was collected after 
$24 \mathrm{~h}$ and the nematodes per $5 \mathrm{ml}$ of suspension were counted in a counting dish. After 90 days of inoculation the roots of the eggplants were uprooted carefully from the pots and were washed under running tap water to remove all dust particles on the root. The water present in the plants was eliminated by pressing them between blotting sheets. Plant growth parameters including the length $(\mathrm{cm})$, fresh and dry weights (g), and yield/plant (g) were estimated. The following biochemical and pathological parameters were also examined; percent of pollen fertility, chlorophyll content $\left(\mathrm{mg} \cdot \mathrm{g}^{-1}\right)$, carotenoid content $\left(\mathrm{mg} \cdot \mathrm{g}^{-1}\right)$, phenolic content $\left(\mathrm{mg} \cdot \mathrm{g}^{-1}\right)$, peroxidase (units $\cdot \mathrm{g}^{-1}$ fresh weight of roots), catalase (mole $\cdot \mathrm{g}^{-1}$ fresh weight of roots), eggmasses/root, eggs/eggmass, nematode population (per $250 \mathrm{~g}$ soil) and root-knot index (RKI). The number of plants with galled root systems and the root-knot index were expressed on a $0-5$ scale $(0-$ no galling, 1 - 1-2 galling, 2-3-10 galling, 3-11-30 galling, 4 - 31-100 galling, 5 - more than 100 galling per root system according to Taylor and Sasser (1978).

\section{Chlorophyll estimation}

The chlorophyll content in fresh leaves was estimated following the method worked out by Mackinney (1941). The chlorophyll content present in the extract was calculated using the following equation:

Total chlorophyll content $=$

$$
=20.2\left(A_{645}\right)+8.02\left(A_{663}\right) \times\left(\frac{V}{1,000 \times d \times W}\right),
$$

where: $A$ - absorbance of extract (leaf sample) at given wavelength (645 and $663 \mathrm{~nm}$ ), $V$ - final volume, $W$ fresh weight, $d$ - length of path of light.

\section{Carotenoid estimation}

For carotenoid estimation, the procedure for the preparation of extract from the fresh leaves was the same as that of chlorophyll estimation. However, the absorbance of extract was read at the wavelength of 480 and $510 \mathrm{~nm}$ against blank (80\%) acetone on a spectrophotometer. The carotenoid content present in the extract was calculated by using the following formula:

Carotenoid content $=$

$$
=7.6\left(A_{480}\right)-1.49\left(A_{510}\right) \times\left(\frac{V}{1,000 \times d \times W}\right) \text {. }
$$

\section{Estimation of total phenolic substances}

The total phenolic content of the extracts was determined by the Folin-Ciocalteu method (Kaur et al.
2002). All chlorophyll, carotenoid and phenolics contents were expressed as $\mathrm{mg} \cdot \mathrm{g}^{-1}$ tissue.

\section{Estimation of peroxidase}

The enzyme activity of peroxidase was determined by using pyrogallol as a substrate following the method given by Raja and Dasgupta (1986).

\section{Estimation of catalase}

Catalase activity was determined by consumption of $\mathrm{H}_{2} \mathrm{O}_{2}$ using the method of Dhindsa et al. (1981).

\section{Statistical analysis}

Data collected were subjected to statistical analysis using one-way analysis of variance (ANOVA) using SPSS 17.00 software (SPSS Inc., Chicago, IL, USA). Duncan's multiple range test was employed to test for significant differences between the treatments. Means in each column followed by the same letter are not significantly different according to Duncan's multiple range test $(\mathrm{DMRT})$ at $\mathrm{p} \leq 0.05$.

\section{Results}

The experimental results revealed the beneficial effects of chitosan alone and in combination with various agricultural wastes on the growth and growth yielding attributes of eggplant under greenhouse conditions (Table 1). All the treatments either alone or in combination showed differential responses in terms of growth characters and reduction in the nematode infestation. Chitosan combined with various agricultural wastes had a significant influence on the growth attributes of eggplant viz., length, fresh and dry weights, pollen fertility, yields as well as total chlorophyll and carotenoid content. When compare to untreated applications (nematodes alone). Tables 1, 2 and 3 show clearly that combined applications of chitosan with various agricultural wastes viz., onion, menthe, brassica, urad, coconut shell, groundnut and corn cob waste significantly improve the different growth and physiological parameters of eggplant and suppressed the disease level in terms of the number of galls per plant, the number of egg masses per plant and the number of eggs per individual egg mass at $(p \leq 0.05)$ in all the treatments. There was a significant reduction in all the nematode infested parameters in comparison to the control. Plant growth parameters in terms of length, fresh and dry weights of plants were the highest in the combined application of chitosan with onion (Fig. 1). The followings combinations gave the next highest parameters: chitosan 
+ mentha, chitosan + Brassica, chitosan + urad, chitosan + coconut, chitosan + groundnut and chitosan + corn cob and the low were detected in the application of chitosan alone. The application of chitosan in combination with agricultural wastes showed synergistic effects and thereby resulted in the augmentation of plant growth characters which ultimately resulted in greater suppression of the root-knot disease than chitosan alone. In addition to improving the growth parameters of eggplant chitosan combined with various agricultural wastes physiological parameters were also enhanced viz., chlorophyll, carotenoid and pollen fertility. The chlorophyll content of eggplant leaves was significantly higher with applying chitosan combined with various agricultural wastes. Of all the tested agricultural wastes, onion waste with chitosan was the most efficient in improving the chlorophyll and carotenoid contents when compared to other treatments and the least was found with chitosan alone. In the untreated control the lowest value was detected when the plants were inoculated with nematode. With nematode inoculation, the chlorophyll content decreased significantly, whereas it increased significantly on applying chitosan with various agricultural wastes. Significant increases in the pollen fertility and yield also occurred with chitosan in combination with menthe $(85 \%$ and $360 \mathrm{~g}$, respectively), followed by the combined treatment of chitosan + onion and chitosan + Brassica,

Table 1. Effect of chitosan alone and in combination with agricultural wastes on growth of eggplant cv. 'BR-112' in relation to root-knot development caused by Meloidogyne incognita

\begin{tabular}{lccccc}
\hline \multicolumn{1}{c}{ Treatments } & $\begin{array}{c}\text { Length } \\
{[\mathrm{cm}]}\end{array}$ & $\begin{array}{c}\text { Fresh weight } \\
{[\mathrm{g}]}\end{array}$ & $\begin{array}{c}\text { Dry weight } \\
{[\mathrm{g}]}\end{array}$ & $\begin{array}{c}\text { Pollen fertility } \\
{[\%]}\end{array}$ & $\begin{array}{c}\text { Yields } \\
{[\mathrm{g}]}\end{array}$ \\
\hline Chitosan & $66 \mathrm{~g}$ & $55.0 \mathrm{~h}$ & $17.2 \mathrm{~h}$ & $73.2 \mathrm{~b}$ & $290 \mathrm{f}$ \\
Chitosan + mentha & $78.5 \mathrm{bc}$ & $69.5 \mathrm{bc}$ & $28.0 \mathrm{bc}$ & $85.0 \mathrm{ab}$ & $370 \mathrm{ab}$ \\
Chitosan + coconut & $73.0 \mathrm{de}$ & $62.6 \mathrm{ef}$ & $23.0 \mathrm{ef}$ & $79.2 \mathrm{ab}$ & $333 \mathrm{cde}$ \\
Chitosan + groundnut & $71.5 \mathrm{ef}$ & $60.0 \mathrm{fg}$ & $21.4 \mathrm{fg}$ & $77.0 \mathrm{~b}$ & $320 \mathrm{def}$ \\
Chitosan + corn cob & $69.7 \mathrm{fg}$ & $58.0 \mathrm{gh}$ & $20.0 \mathrm{gh}$ & $75.5 \mathrm{~b}$ & $306 \mathrm{ef}$ \\
Chitosan + onion & $81.5 \mathrm{ab}$ & $72.0 \mathrm{ab}$ & $30.0 \mathrm{~b}$ & $83.2 \mathrm{ab}$ & $360 \mathrm{bc}$ \\
Chitosan + Brassica & $76.4 \mathrm{~cd}$ & $67.2 \mathrm{~cd}$ & $26.5 \mathrm{~cd}$ & $82.0 \mathrm{ab}$ & $350 \mathrm{bcd}$ \\
Chitosan + urad & $74.6 \mathrm{de}$ & $65.4 \mathrm{de}$ & $24.8 \mathrm{de}$ & $80.4 \mathrm{ab}$ & $341 \mathrm{bcd}$ \\
UUC & $86.0 \mathrm{a}$ & $76.4 \mathrm{a}$ & $34.2 \mathrm{a}$ & $90.2 \mathrm{a}$ & $394 \mathrm{a}$ \\
UIC & $42.0 \mathrm{e}$ & $31.5 \mathrm{e}$ & $13.4 \mathrm{f}$ & $51.5 \mathrm{c}$ & $200 \mathrm{~g}$ \\
\hline
\end{tabular}

Values are the mean s of 4 replicates; Initial inoculum = 1,500 (J2) of Meloidogyne incognita per pot; UUC - Untreated Uninoculated Control; UIC - Untreated Inoculated Control. Values in each column followed by the same letters are not significantly different according to Duncan's Multiple Range Test (DMRT) at $(p \leq 0.05)$

Table 2. Effect of chitosan alone and in combination with agricultural wastes on eggplant cv. 'BR-112' in relation to root-knot development and multiplication of Meloidogyne incognita

\begin{tabular}{lcccc}
\hline Treatments & Eggmasses/root & Eggs/eggmass & $\begin{array}{c}\text { Nematode popula- } \\
\text { tion in } 250 \mathrm{~g} \\
\text { of soil sample }\end{array}$ & RKI \\
\hline Chitosan & $75 \mathrm{~b}$ & $111 \mathrm{~b}$ & $800 \mathrm{~b}$ & $3.0 \mathrm{~b}$ \\
Chitosan + mentha & $25 \mathrm{~g}$ & $37 \mathrm{~h}$ & $545 \mathrm{~h}$ & $1.2 \mathrm{~cd}$ \\
Chitosan + coconut & $49 \mathrm{~cd}$ & $82 \mathrm{e}$ & $672 \mathrm{e}$ & $2.1 \mathrm{bc}$ \\
Chitosan + groundnut & $53 \mathrm{~cd}$ & $94 \mathrm{~cd}$ & $716 \mathrm{~d}$ & $2.4 \mathrm{bc}$ \\
Chitosan + corn cob & $59 \mathrm{c}$ & $100 \mathrm{c}$ & $776 \mathrm{c}$ & $2.8 \mathrm{~b}$ \\
Chitosan + onion & $22 \mathrm{gh}$ & $30 \mathrm{hi}$ & $515 \mathrm{i}$ & $1.4 \mathrm{~cd}$ \\
Chitosan + Brassica & $33 \mathrm{ef}$ & $50 \mathrm{~g}$ & $590 \mathrm{~g}$ & $2.0 \mathrm{bc}$ \\
Chitosan + urad & $40 \mathrm{e}$ & $66 \mathrm{f}$ & $620 \mathrm{f}$ & $0 \mathrm{e}$ \\
UUC & $0 \mathrm{i}$ & $0 \mathrm{j}$ & $0 \mathrm{j}$ & $5 \mathrm{a}$ \\
UIC & $162 \mathrm{a}$ & $270 \mathrm{a}$ & $1,600 \mathrm{a}$ & \\
\hline
\end{tabular}

Values are the means of 4 replicates; Initial inoculum = 1,500 (J2) of Meloidogyne incognita per pot; UUC - Untreated Uninoculated Control; UIC - Untreated

Inoculated Control; RKI - root-knot index. Values in each column followed by the same letters are not significantly different according to Duncan's Multiple Range Test (DMRT) at $(p \leq 0.05)$ 
Table 3. Effect of chitosan alone and in combination with agricultural wastes on antioxidants enzymes and biochemical parameters of eggplant cv. 'BR-112' in relation to root-knot development caused by Meloidogyne incognita

\begin{tabular}{lccccc}
\hline \multicolumn{1}{c}{ Treatments } & $\begin{array}{c}\text { Chlorophyll } \\
{\left[\mathrm{mg} \cdot \mathrm{g}^{-1}\right]}\end{array}$ & $\begin{array}{c}\text { Carotenoid } \\
{\left[\mathrm{mg} \cdot \mathrm{g}^{-1}\right]}\end{array}$ & $\begin{array}{c}\text { Phenolic } \\
\text { content } \\
{\left[\mathrm{mg} \cdot \mathrm{g}^{-1}\right]}\end{array}$ & $\begin{array}{c}\text { Peroxidase } \\
{\left[\begin{array}{c}\text { Canits } \cdot \mathrm{gm}^{-1} \mathrm{fresh} \\
\text { weight of roots] }\end{array}\right.}\end{array}$ & $\begin{array}{c}\text { [mole } \cdot \mathrm{gm}^{-1} \text { fresh } \\
\text { weight of roots] }\end{array}$ \\
\hline Chitosan & $1.72 \mathrm{f}$ & $0.556 \mathrm{~h}$ & $0.902 \mathrm{~b}$ & $1.96 \mathrm{ab}$ & $6.89 \mathrm{~b}$ \\
Chitosan + mentha & $2.24 \mathrm{bc}$ & $0.745 \mathrm{bc}$ & $0.742 \mathrm{gh}$ & $1.33 \mathrm{fg}$ & $5.27 \mathrm{gh}$ \\
Chitosan + coconut & $1.99 \mathrm{cde}$ & $0.660 \mathrm{de}$ & $0.844 \mathrm{de}$ & $1.66 \mathrm{de}$ & $6.01 \mathrm{de}$ \\
Chitosan + groundnut & $1.95 \mathrm{def}$ & $0.628 \mathrm{ef}$ & $0.873 \mathrm{~cd}$ & $1.71 \mathrm{~cd}$ & $6.22 \mathrm{~cd}$ \\
Chitosan + corn cob & $1.88 \mathrm{ef}$ & $0.600 \mathrm{fg}$ & $0.893 \mathrm{bc}$ & $1.87 \mathrm{bc}$ & $6.63 \mathrm{bc}$ \\
Chitosan + onion & $2.30 \mathrm{~b}$ & $0.780 \mathrm{~b}$ & $0.712 \mathrm{hi}$ & $1.26 \mathrm{gh}$ & $5.08 \mathrm{hi}$ \\
Chitosan + Brassica & $2.16 \mathrm{bcd}$ & $0.692 \mathrm{~cd}$ & $0.796 \mathrm{fg}$ & $1.42 \mathrm{ef}$ & $5.52 \mathrm{fg}$ \\
Chitosan + urad & $2.04 \mathrm{bcde}$ & $0.680 \mathrm{~cd}$ & $0.816 \mathrm{ef}$ & $1.50 \mathrm{ef}$ & $5.81 \mathrm{ef}$ \\
UUC & $2.60 \mathrm{a}$ & $0.980 \mathrm{a}$ & $0.650 \mathrm{j}$ & $1.13 \mathrm{~h}$ & $4.68 \mathrm{j}$ \\
UIC & $1.28 \mathrm{~g}$ & $0.325 \mathrm{i}$ & $0.986 \mathrm{a}$ & $2.12 \mathrm{a}$ & $7.87 \mathrm{a}$ \\
\hline
\end{tabular}

Values are the means of four replicates; Initial inoculum =1,500 (J2) of Meloidogyne incognita per pot; UUC - Untreated Uninoculated Control; UIC - Untreated Inoculated Control. Values in each column followed by the same letters are not significantly different according to Duncan's Multiple Range Test (DMRT) at $(p \leq 0.05)$

whereas the least was with chitosan alone $(73.2 \%$ and 290 g) respectively. The phenolic content increased significantly in the leaves of eggplant. Plants had a maximum limit of $0.986 \mathrm{mg} \cdot \mathrm{g}^{-1}$ after infestation with M. incognita when compared to the treated plants. However, among the treated plants the maximum phenolic content of $0.893 \mathrm{mg} \cdot \mathrm{g}^{-1}$ was displayed by chitosan in combination with corn cob. Similar findings were noted for the peroxidase and catalase activities with the highest value detected in the inoculated control with $M$. incognita where no treatment was given (2.12 units $\cdot \mathrm{g}^{-1}$ and $7.87 \mathrm{~mole} \cdot \mathrm{g}^{-1}$ ) as compared to the lowest level of activities in those treated with the chitosan + onion (1.26 units $\cdot \mathrm{g}^{-1}$ and $5.08 \mathrm{~mole} \cdot \mathrm{g}^{-1}$, respectively) (Table 3). Moreover, in the plants which were neither treated with any of the treatments nor inoculated with $M$. incognita juveniles were observed the least. The potential of chitosan with different agricultural wastes in the management of root-knot nematode was assessed from the reduction in nematode infestation and improvement in the growth and

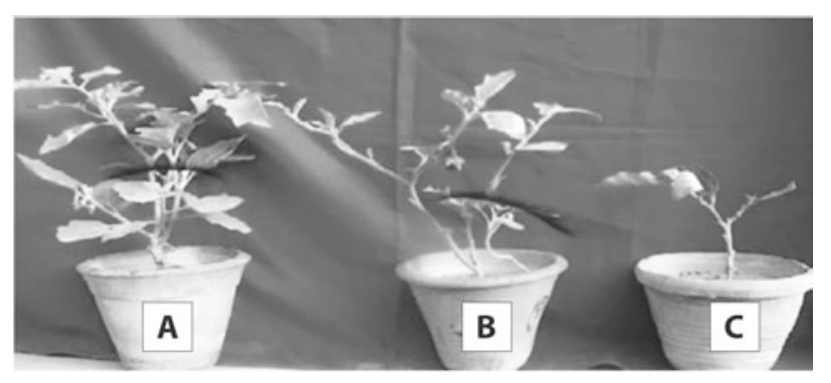

Fig. 1. Effect of chitosan in combination with agricultural wastes on eggplant: A - chitosan + onion, B - chitosan + mentha, C control (nematode) growth yielding attributes of the host crop. Maximum reduction in various pathological parameters viz., eggmasses/root, eggs/eggmass, nematode population and root-knot indices were demonstrated when the plant were treated with chitosan + onion and the least was observed with chitosan alone (Table 2). All the plant growth parameters were shown to be affected positively when treated with combined application of chitosan + onion, chitosan + mentha, chitosan + Brassica, chitosan + urad, chitosan + coconut, chitosan + groundnut and chitosan + corn cob against $M$. incognita on eggplant. It was found that amendment with chitosan alone also caused significant reductions in nematode infestation and enhancement in plant growth parameters but was not as effective as combined treatments with the various tested agricultural wastes. In our studies chitosan with onion proved to be the most effective against root-knot nematode infestations. However, our results suggest that the plant treated with chitosan + onion, chitosan + mentha, chitosan + Brassica had direct and indirect effects on nematode reproduction which ultimately resulted in improved plant growth characters. Therefore, it can also be suggested that infestation caused by root-knot nematode, $M$. incognita could be lowered by the combined application of chitosan with agricultural wastes in view of an eco-friendly environment.

\section{Discussion}

The results of our study demonstrated that amending the soil with chitosan in combination with agricultural wastes viz., onion, mentha, Brassica, urad, coconut, groundnut and corncob enhanced the growth and 
growth yielding attributes of eggplant, and suppressed root-knot infestation of $M$. incognita both in the soil and root systems under greenhouse conditions. The data obtained from Tables 1, 2, 3 revealed that the treatment with chitosan + onion, chitosan + mentha and chitosan + Brassica performed the best in enhancing the plant growth characters and in curbing rootknot disease. Other treatments viz., chitosan + urad, chitosan + coconut, chitosan + groundnut and chitosan + corn cob were less effective in reducing nematode infestation and enhancement of plant growth parameters. The efficacy of all the treatments varied differentially and were dependent on the releas of chemicals on the decomposition and promotion of soil enriching rhiozoflora and fauna. In addition to this, a synergistic effect also acts as a prominent factor. Our results complement those of Tariq and Siddiqui (2005) and Ahmad and Siddiqui (2009) who demonstrated that organic soil amendments affect the reproduction of nematodes and increase the growth and yield of plants. Chitosan combined with onion waste effectively controlled root-knot nematode disease and improved plant growth as well as the yield of eggplant. This may be due to the release of various phytochemicals after the decomposition of onion waste which may disturb the life cycle and thereby reduce the rate of reproduction. In addition to this release sulfur may cause fumigation in the soil that might suppress the respiratory rate and ultimately may cause mortality of the juveniles. Other treatments with chitosan with mentha waste and chitosan with Brassica seems to be lethal to the survivability of root-knot nematodes, $M$. incognita because of the presence of various medicinally important phytoconstituents. The essential oils obtained from Mentha spp. have been shown to possess antibacterial, antifungal, antiviral, insecticidal and antioxidant properties (Kordali et al. 2005). The addition of organic matter as soil amendments affects microbial decomposition due to the release of various chemical compounds which alter chemical, biological and physical properties and improves soil health. This favours beneficial soil rhizospheric activity and microbial populations that through different tactics such as completion, antibiosis or parasitism could hamper plant diseaseprovoking agents including fungi, bacteria and nematodes. Addition of soil amendments results in a considerable increase in the liberation of $\mathrm{CO}_{2}$ through the saprophytic activities of soil saprophytes which can suppress disease causing agents (Papavizas et al. 1962). Furthermore this release of exudates increases soil fertility and improve soil texture. Moreover, released chemical act as a defense activator and may provide resistance to the root of the plants. Adding amendments to soil may alter many factors that affect nematodes directly, including soil structure, particle aggregation, $\mathrm{pH}$, salinity and levels of carbon dioxide, oxygen and other chemicals (Oka 2010). Brassica green manures suppressed root-knot nematodes significantly in controlled environments due to the involvement of various phytoconstituents such as isothiocyanates and glucosinolates (Brown and Morra 1997). Glucosinolate on decomposition release various allelochemicals that control soil-borne pests, insects and nematodes (Cutro et al. 2005). Many compounds with nematicidal activity have been found in plants including alkaloids, flavonoids, saponins, phenol, tannins, diterpenes, glucosinolates, isothiocyanates, phenols, polyacetylenes, sesquiterpenes and thienyls (Asif et al. 2017). Recent research demonstrated that phenolics, flavonoids, saponin, alkaloid and tannins obtained from Allium spp, (Huzaifa et al. 2014) shown nematicidal properties. Some agricultural wastes have been exploited as an alternative means of nematode control (Abubakar and Majeed 2000; Hassan et al. 2010). Many plant residues and other amendments can release nitrogen compounds, organic acids, or other compounds that may have adverse effects on nematodes (Oka 2010). Chitosan is a naturally-occurring and ecologically friendly biopesticide substance that reduces root-knot nematode infection and nematode populations in various agricultural and horticultural crops. All the waste materials combined with chitosan showed nematostatic and nematicidal activity. Chitosan used to control plant pathogens has been extensively explored with varying degree of success depending on the pathosystem, the derivatives used, concentration, degree of deacylation, viscosity and the applied formulation (ElHadrami et al. 2010). Further microbial activity results in deamination of the sugar and accumulation of ammonium ions and nitrates (Rodriguez-Kabana et al. 1983). Nematicidal concentrations of ammonia in association with newly formed chitinolytic microflora are believed to cause nematode suppressiveness (Godoy et al. 1983). The application of chitosan seemed therefore to decrease the severity of the disease, probably due to the impairment of nematode reproduction and/or to the induction of physiological alterations in both nematodes and plants (Khalil and Badawy 2012), which did not allow successful reproduction of the nematodes. Chitosan provides possible resistance to plants by exhibiting the elicitor activity through inducing the local and systemic resistance of tomato to the root-knot nematode, $M$. incognita. Our results agree with Aboud et al. (2002) who revealed the potential of chitosan against the infection of $M$. javanica in a greenhouse and field trial on tomato plants. It has been welldocumented that incompatibility to nematodes expressed after infection and active mechanisms involved compounds produced post inflectionally rather than performed on constitutive plant products (Zacheo et al. 
1987). In response to this, plants develop defense mechanisms as the nematode invades. Most of these defense mechanisms are cause incompatible resistant interactions between plants and pathogens of which the formation of reactive oxygen species (ROS) is common (Montes et al. 2004). Formation of reactive oxygen species caused lipid peroxidation which after invasion of a pathogen leads to cell death. Therefore, augmenting the rates of phenolics, catalase and peroxidase in the hosts in response to $M$. incognita infection in the current research work restrict the nematode invasion and worked as defence factor as against to the healthy plants. Increased peroxidase activity is associated with a resistant reaction due to increased phenolic contents hence influences the resistance (Giebel 1974). Our results agree with Sujatha and Mehta (1998) who stated that greater peroxidase activity was detected in nematode inoculated plants than in the untreated control. It was also demonstrated that the incorporation of chitin can influence the physicochemical properties of the soil, releasing nematicidal compounds such as organic acids and nitrogen compounds $\left(\mathrm{NH}_{3}\right)$ and inducing plant resistance by increasing antagonist microorganisms in the soil (Oka 2010). The addition of chitosan alone and in combination with agricultural wastes significantly improve plant growth characters and abated the root-knot disease. The pot experiment manifested that organic amendment, particularly chitosan may assist the plants especially the susceptible cultivar of eggplant, to combat root-knot nematode infestation through the stimulation and manufacture of defense compounds and modulation of the soil's biological and physical properties which promote soil conditioning and improves soil health, eventually supportings the beneficial soil rhizoflora. Combining chitosan with an organic amendment can abolish plant pests and promote sustainable integrated pest management programme. Currently, emphasis is placed on improving the efficiency of organic amendments since they not only provide carbon and nutritional elements but also play a crucial role in sustaining long term soil fertility. Soil with organic carbon favours its physical, chemical and biological properties which in response proceed to manage and strengthen soil fertility.

\section{Conclusion}

The studies showed that efficient management of the nematode problem may be done by using chitosan alone and combined with agricultural wastes viz., onion waste, menthe waste and Brassica waste. The integrated treatment not only annihilates the pathogenic effect of the nematodes but also improves yield. This method may minimize the toxicity and hazardous nature of chemical nematicides in the environment. However, it is necessary to further affirm the results under micro plot and field conditions as well as characterize and identify the involvement of chemicals and beneficial microbial populations. The interactions between the various synergistic components and mechanisms involved should be properly understood.

\section{Acknowledgements}

The authors greatly appreciate the Department of Science and Technology, New Delhi under the DST PURSE programme for financial assistance Project No. F.6-5-EP/DS/224 and the Chairman Department of Botany, AMU, Aligarh, for providing necessary facilities during the course of studies.

\section{References}

Aboud H.M., Fattah F.A., Al-Heeti A.A., Saleh H.M. 2002. Efficiency of chitosan in inducing systemic acquired resistance against the root-knot nematode (Meloidogyne javanica (Treub) Chitwood) on tomato. Arab Journal of Plant Protection 20 (2): 93-98.

Abubakar U., Majeed Q. 2000. Use of animal manure for the control of root-knot nematodes of tomato. Journal of Agriculture and Environment 1 (12): 29-33.

Ahmad F., Siddiqui M.A 2009. Promising organic additives for them management of root knot nematode, Meloidogyne incognita. Indian Journal of Nematology 39 (2): 246-249.

Asif M., Tariq M., Khan A., Siddiqui M.A. 2016. Sustainable management of root knot nematode Meloidogyne incognita through organic amendment on Solanum lycopersicum L. Asian Journal of Biology 1 (1): 1-8. DOI: https://doi.org/10.9734/ajob/2016/30739

Asif M., Tariq M., Khan A., Siddiqui M.A. 2017. Biocidal and antinemic properties of aqueous extracts of Ageratum and Coccinia against root-knot nematode, Meloidogyne incognita in vitro. The Journal of Agricultural Sciences 12 (2): 108-122. DOI: https://doi.org/10.4038/jas.v12i2.8229

Brown P.D., Morra M.J. 1997. Control of soil-borne plant pests using glucosinolates-containing plants. Advances in Agronomy 61: 167-231. DOI: https://doi.org/10.1016/s00652113(08)60664-1

Burkett-Cadena M., Kokalis-Burelle N., Lawrence K.S., van Santen E., Kloepper J.W. 2008. Suppressiveness of root-knot nematodes mediated by rhizobacteria. Biological Control 47 (1): 55-59. DOI: https://doi.org/10.1016/j.biocontrol.2008.07.008

Curto G., Dallavalle E., Lazzeri L. 2005. Life cycle of duration of Meloidogyne incognita and host status of Brassicaceae and Capparaceae selected for glucosinolate content. Nematology 7 (2): 203-212. DOI: https://doi.org/ $10.1163 / 1568541054879494$

Curto G., Lazzeri L., Dallavalle E., Santi R., Malaguti L. 2006. Effectiveness of crop rotation with Brassicaceae species for the management of the southern root-knot nematode $\mathrm{Me}$ loidogyne incognita. Abstracts 2nd International Biofumigation Symposium, June 25-29, Moscow, Russia, 51 pp.

Daykin M.E., Hussey R.S 1985. Staining and histo-pathological techniques in nematology. p. 39-48. In: "An Advanced Treatise on Meloidogyne" (K.R. Barker, C.C. Carter, J.N. Sasser, eds.). Volume II. Raleigh, NC: North Carolina State University Graphics, USA. 
Dhindsa R.S., Plumb-Dhindsa P., Thorpe T.A. 1981. Leaf senescence correlated with increased levels of membrane permeability and lipid peroxidation, and decrease levels of superoxide dismutase and catalase. Journal of Experimental Botany 32 (1): 93-101. DOI: https://doi.org/10.1093/ $\mathrm{jxb} / 32.1 .93$

El-Hadrami A., Lorne R.A., El-Hadrami I., Daayf F. 2010. Chitosan in Plant Protection. Marine Drugs 8 (4): 968-987. DOI: $10.3390 / \mathrm{md} 8040968$

FAO. 2011. Food and Agriculture Organization. Available on: http://fao.org/docrep/013/i2050e/i2050e00.htm. [Accessed: 15 May 2017]

Giebel J. 1974. Biochemical mechanism of plant resistance to nematodes - a review. Journal of Nematology 6 (4): 175-184.

Godoy G., Rodriguez-Kabana R., Shelby R.A., Morgan-Jones G. 1983. Chitin amendments for control of Meloidogyne arenaria in infested soil. II. Effects on microbial population. Nematropica 13: 63-74.

Hassan M.A., Chindo P.S., Marley P.S. Alegbejo M.D. 2010. Management of root-knot nematodes, (Meloidogyne spp.) on tomato (Lycopersicon lycopersicum) using organic wastes in Zaria, Nigeria. Plant Protecion Science 46: 34-39.

Huzaifa U., Labaran I., Bello A.B.,Olatunde A. 2014. Phytochemical screening of Aqueous extracts of Garlic (Allium sativum) bulbs. Report and Opinion 6 (8): 1-4.

Kaur C., Kapoor H.C. 2002. Anti-oxidant activity and total phenolic content of some Asian vegetables. International Journal of Food Science and Technology 37 (2): 153-161. DOI: https://doi.org/10.1046/j.1365-2621.2002.00552.x

Khalil M.S., Badawy M.E. 2012. Nematicidal activity of a biopolymer chitosan at different molecular weights against root-knot nematode, Meloidogyne incognita. Plant Protection Science 48: 170-178.

Kordali S., KotanR., Mavi A., Cakir A., Ala A., Yildirim A. 2005. Determination of the chemical composition and antioxidant activity of the essential oil of Artemisia dracunculus and of the antifungal and antibacterial activities of Turkish Artemisia absinthium, A. dracunculus, Artemisia santonicum and Artemisia spicigera essential oils. Journal of Agricultural and Food Chemistry 53 (24): 9452-9458. DOI: https://doi. org/10.1021/jf0516538

Luc M., Sikora A., Bridge J. 2005. Plant parasitic nematodes in subtropical and tropical agriculture. CABI, Wallingford, UK, 2nd edition, $871 \mathrm{pp}$

Mackinney G. 1941. Absorption of light by chlorophyll solutions. Journal of Biolgical Chemistry 140: 315-322.

Montes M.J., Lopez-Brana I., Delibes A. 2004. Root enzyme activities associated with resistance to Heterodera avena ecoferred by gene Cre7 in wheat, Aegilops triuncialis introgression line. Journal of Plant Physiology 161 (4): 493-495. DOI: https://doi.org/10.1078/0176-1617-01165

Oka Y. 2010. Mechanisms of nematode suppression by organic soil amendments - a review. Applied Soil Ecology 44 (2): 101-115. DOI: https://doi.org/10.1016/j.apsoil. 2009.11.003

Papavizas G.C., Davey C.B., Woodard R.S. 1962. Comparative effectiveness of some organic amendments and fungici- des in reducing activity and survival of Rhizoctonia solani in soil. Canadian Journal of Microbiology 8 (6): 915-922. DOI: https://doi.org/10.1139/m62-119

Ploeg A. 2008. Biofumigation to manage plant-parasitic nematodes. p. 239-248. In: "Integrated Management and Biocontrol of Vegetable and Grain Crops Nematodes" (A. Ciancio, K.G. Mukerji, eds.). Integrated Management of Plant Pests and Diseases. Volume 2, Springer Netherlands. DOI: https:// doi.org/10.1007/978-1-4020-6063-2_12

Rabea E.I., Badawy M., Stevens C.V., Smagghe G., Steurbaut W. 2003. Chitosan as antimicrobial agent: applications and mode of action. Biomacromolecules 4 (6): 1457-1465. DOI: https://doi.org/10.1021/bm034130m

Radwan M.A., Abu-Elamayem M.M., Farrag S.A.A., Ahmed N.S. 2011. Integrated management of Meloidogyne incognita infecting tomato using bio-agents mixed with either oxamyl or organic amendments. Nematologia Mediterranea 39 (2): 151-156.

Radwan M.A., Farrag S.A.A., Abu-Elamayem M.M., Ahmed N.S. 2012. Extraction, characterization, and nematicidal activity of chitin and chitosan derived from shrimp shell wastes. Biology and Fertility of Soils 48 (4): 463-468. DOI: https://doi.org/10.1007/s00374-011-0632-7

Raja A., Dasgupta D.R. 1986. Enhance synthesis of messenger RNA in relation to resistance-expression in cowpea (Vigna unguiculata) infected with the root knot nematode. Review de Nematology 9 (1): 35-38.

Rodriguez-Kabana R., Godoy G., Morgan-Jones G., Shelby R.A. 1983. The determination of soil chitinase activity: conditions for assay and ecological studies. Plant and Soil 75 (1): 95-106. DOI: https://doi.org/10.1007/bf02178617

Sikora R.A., Fernandez E. 2005. Nematode parasites of vegetables. p. 319-392. In: "Plant Parasitic Nematodes in Subtropical and Tropical Agriculture" (M. Luc, R.A. Sikora, J. Bridge, eds). CABI Publishing, Wallingford. DOI: $10.1079 / 9780851997278.0000$

Singh R.V., Sharma H.K. 1998. Nematode Diseases in Plants. New Delhi: CBS Publishers and Distributors. Nematode problems and their management in vegetable crops 252-268.

Sujatha K., Usha Mehta K. 1998. Changes in the activity of peroxidase and polyphenol oxidases in sugarcane root after infection with Pratylenchus zeae and Meloidogyne javanica. Afro Asian Journal of Nematology 2: 80-83.

Tariq I., Siddiqui M.A. 2005. Evaluation of nematicidal properties of neem for the management of Meloidogyne incognita on tomato. Indian Journal Nematology 35: 56-58.

Taylor A.L., Sasser J.N. 1978. Biology, Identification and Control of Root-knot Nematodes (Meloidogyne species). A Cooperative Publication of the Department of Plant Pathology North Carolina State University and the United States Agency for International Development, Printed by North Carolina State University Graphics.

Zacheo G., Beleve-Zacheo T., Pricolo G. 1987. Metabolic changes in enzyme levels in potato roots infested by potato cyst nematode, Globodera pallida (Pa3) and Globodera rostochiensis (R01). Nematologia Mediterranea 15 (2): 293-302. 